\title{
BAURAN PEMASARAN SEBAGAI PENUNJANG PENINGKATAN WISATAWAN KE MUSEUM BALI ${ }^{1}$
}

Oleh: Heri Purwanto dan Coleta Palupi Titasasi

Arkeologi, Fakultas Ilmu Budaya Universitas Udayana

Email: heri.arkeo@gmail.com

\begin{abstract}
Abstrak
Museum Bali merupakan salah satu tempat daya tarik wisata yang begitu terkenal di Kota Denpasar. Bahkan dijadikan sebagai wisata kota oleh pemerintah setempat dalam rangkaian city tour. Artikel ini melihat peranan bauran pemasaran dalam menunjang peningkatan wisatawan yang datang ke Museum Bali. Unsur-unsur yang dilihat adalah produk, harga, tempat, dan promosi. keempat komponen tersebut mempelihatkan hasil kerjanya yang memuaskan, karena ia mampu mempergaruhi pemutusan seseorang berlibur ke Museum Bali. Penelitian ini mengunakan metode pengumpulan data berupa studi pustaka, observasi diikuti dengan wawancara.
\end{abstract}

Kata Kunci: Museum Bali, Bauran Pemasaran, Wisatawan.

\begin{abstract}
Museum Bali is one of the famous tourist object in Denpasar City. Museum Bali even became the icon of Denpasar City Tour by the government. This article is happen to see the role of marketing mixture in purpose to support the increase of tourists visit to museum Bali. The variables used in this article are the product, the price, the place, and the promotion. The four of those components give the satisfying results, because they are capable to influence the tourists decision to visit museum Bali. This research using collecting data methods such as literature review, observation, and interview.
\end{abstract}

Keyword: Museum Bali, Marketing Mixture, Visit.

\footnotetext{
${ }^{1}$ Artikel ini merupakan hasil penelitian tahun 2014, tugas dari Mata Kuliah Metode Sejarah.
} 
Pendahuluan

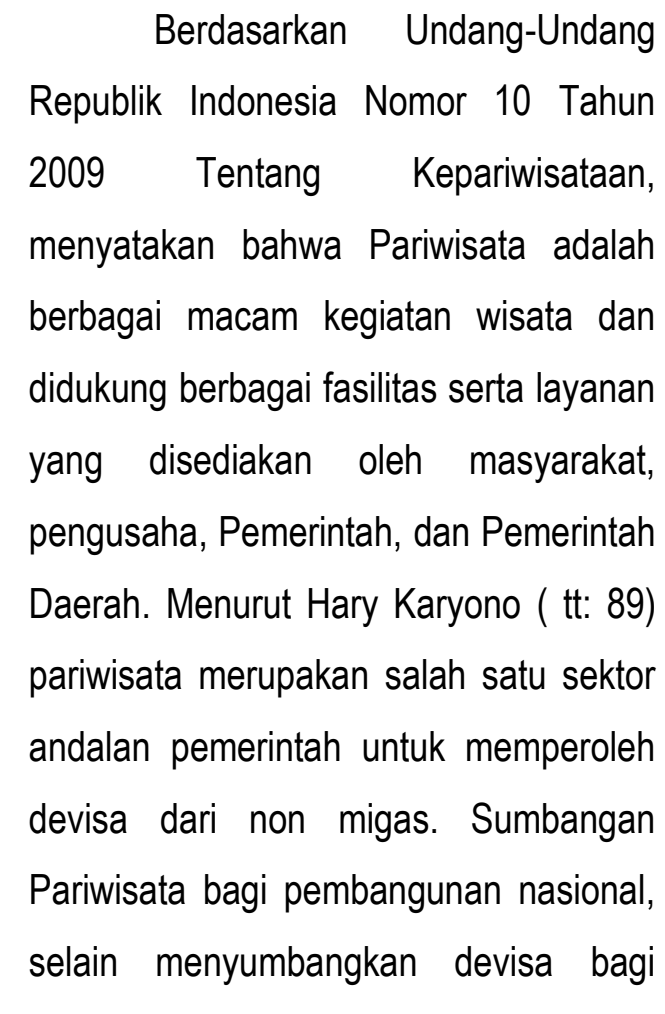
Negara, pariwisata, juga mempunyai peran yang strategis dalam pembangunan nasional, yaitu memperluas lapangan usaha, memperluas lapangan kerja, meningkatkan pendapatan masyarakat dan pemerintah, mendorong pelestarian dan pengembangan budaya bangsa, memperluas wawasan nusantara, mendorong perkembangan daerah, mendorong pelestarian lingkungan hidup, dan menumbuhkan rasa cinta tanah air.

Indonesia memiliki potensi alam, kebudayaan serta adat istiadat yang menjadikan Indonesia sebagai tujuan pariwisata. Pemerintah dewasa ini memasukkan museum sebagai objek pariwisata selain potensi alam, kebudayaan serta adat istiadat. Dukungan pemerintah terhadap perkembangan pariwisata di Indonesia melalui Kementrian Kebudayaan dan Pariwisata tahun 2010 melaksanakan program Tahun Kunjungan Museum 2010 (Visit Museum Year 2010), program ini memiliki peranan strategis sebagai penguat revitalisasi museum (Adyaguhyaka, 2011).

ICOM (International Council Of Museum) telah merumuskan definisi museum sebagai berikut: museum merupakan lembaga yang bersifat tetap, tidak mencari keuntungan, melayani masyarakat dan perkembangannya, terbuka untuk umum yang memperoleh, merawat, menghubungkan dan memamerkan untuk tujuan-tujuan studi, pendidikan dan kesenangan, barangbarang pembuktian manusia dan lingkungannya (Ghautama, 2008:15). Berdasarkan Peraturan Pemerintah No. 19 Tahun 1995 Pasal 1 ayat (1) adalah lembaga, tempat penyimpanan, perawatan, pengamanan, dan pemanfaatan benda-benda bukti materiil hasil budaya manusia serta alam dan lingkungannya guna menunjang upaya 
perlindungan dan pelestarian kekayaan budaya bangsa.

Dalam kaitannya dengan museum sebagai objek wisata, kiranya dapat diacu Undang-Undang Republik Indonesia Nomor 9 Tahun 1990 Tentang Kepariwisataan, terutama Bab III, Pasal 4, Ayat I tentang objek dan daya tarik wisata yang bunyinya antara lain sebagai berikut. Objek dan daya tarik wisata terdiri atas :

a. Objek dan daya tarik wisata ciptaan Tuhan Yang Maha Esa, yang berwujud keadaan alam, serta flora dan fauna;

b. Objek dan daya tarik wisata hasil karya manusia yang berwujud museum, peningggalan purbakala, peninggalan sejarah, seni budaya, wisata agro, wisata tirta, wisata buru, wisata petualangan alam, taman rekreasi dan tempat hiburan (Ardika, 2008: 66).

Penelitian tentang potensi tinggalan arkeologi dan museum sebagai objek dan daya tarik wisata dalam pengembangan pariwisata budaya di Kota Denpasar telah nemu kenali bahwa Museum Bali merupakan satu objek wisata kota di Kota Denpasar yang jumlah pengunjungnya cenderung meningkat. ${ }^{2}$ Dengan mengutip hasil penelitiannya Wayan Ardika yang menyatakan bahwa pengunjung yang datang ke Museum Bali sangat di pengerahui oleh adanya media cetak seperti brosur, buku dan travel agent (Ardika, 2008: 71). Dalam hal ini yang disebut dengan pemasaran dan promosi.

Pemasaran museum adalah strategi museum untuk mempromosikan produk museum kepada masyarakat sehingga produknya dikenal oleh masyarakat, diminati oleh masyarakat dan dampaknya bagi museum adalah meningkatnya kunjungan ke museum. Museum harus membangun strategi pemasaran karena dengan menawarkan pengetahuan yang didapat dari museum, koleksi museum dan kemampuan diri yang didapat setelah mengunjungi museum dapat dijadikan strategi dalam menaikkan jumlah pengunjung museum, karena museum sebagai suatu lembaga yang melayani masyarakat dengan memberikan informasi mengenai pendidikan, sejarah, maupun budaya. Dalam hal ini Museum Bali telah melakukan pemasaran dari tahun ke

\footnotetext{
2 Hasil wawancara dengan Dewa Putu Ardana umur 51 tahun, kepala Seksi Edukasi dan Prevarasi Museum Bali di Museum Bali pada Tanggal 30 oktober 2014.
} 
tahun sehingga tidak heran jika pengunjung atau wisatawan di Museum Bali semakin meningkat.

\section{Metode Penelitian}

Ruang Lingkup dalam penelitian ini yaitu Museum Bali yang letaknya di pusat kota Denpasar tepatnya di jalan Mayor Wisnu. Di sebelah baratnya terdapat lapangan yang terkenal dengan lapangan Puputan Badung, sebelah utara Museum Bali terdapat pura Jagatnatha. Kemudian dibelakangnya atau sebelah timur dikelilingi dengan pertokoan dan sebelah selatan berbatasan langsung dengan jalan Kapten Regug.

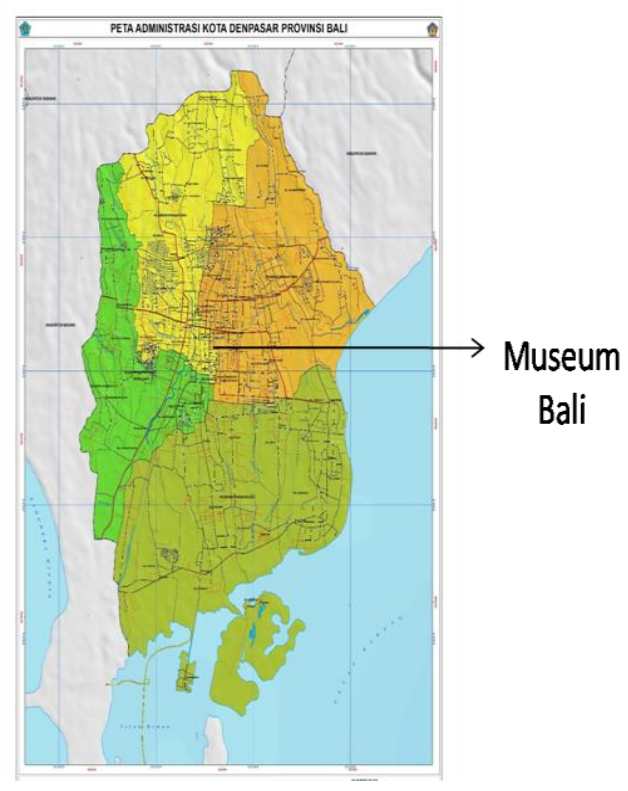

Penelitian Museum Bali

Peta: Lokasi

(sumber:

https://petatematikindo.files.wordpress.c om)

Metode dalam penelitian ini melalui tiga tahap yaitu studi pustaka, observasi dan wawancara. Studi pustaka adalah mencari, mengumpulkan, mempelajari berbagai sumber yang dapat dijadikan litelatur dan ada hubungannya dengan masalah yang ditulis. Literatur tersebut berupa bukubuku, majalah, laporan-laporan ilmiah, skripsi, artikel, makalah, laporan penelitian maupun bentuk publikasi laiinya, sehingga dapat menunjang dalam penyelesaian tulisan ini. Observasi dilakukan dengan pengamatan terhadap objek yang diteliti baik secara langsung maupun tidak langsung. Pengamatan ini diikuti dengan wawancara.

\section{Hasil dan Pembahasan}

1. Pengunjung Museum Bali

Pengunjung yang sering juga disebut dengan wisatawan dalam Undang-Undang Republik Indonesia Nomor 10 Tahun 2009 Tentang Kepariwisataan, menyatakan bahwa wisatawan adalah orang yang melakukan wisata. Museum Bali sebagai salah satu tempat wisata yang banyak diminati oleh para pengunjung dari masyarakat lokal maupun luar negeri harus mempunyai pelayanan yang baik sehingga mampu menarik wisatawan untuk datang ke Museum khususnya Museum Bali. Berdasarkan data yang telah ada pembagian pengunjung yang dilakukan Museum Bali di bagi menjadi dua yaitu pengunjung yang berasal dari Warga Negara Indonesia (WNI) dan 
pengunjung yang berasal dari Warga Negara Asing (WNA). Pembagian pengunjung tidak sampai disitu pengunjung yang berasal dari Warga Negara Indonesia dibagi lagi menjadi beberapa kategori yaitu: Dewasa adalah pengunjung yang berasal dari masyarakat umum yang tidak datang dari pihak sekolah baik dari SMA maupun perguruan tinggi; Anak-anak adalah pengunjung dari masyarakat umum yang tidak datang dari pihak sekolah baik TK maupun SD; Mahasiswa adalah pengunjung yang mengatasnamakan dirinya berasal dari perguruan tinggi tertentu; Pelajar adalah pengunjung yang mengatasnamakan dirinya berasal dari sekolah SMP maupun SMA.

Pengunjung yang berasal dari Warga Negara Asing juga dibagi menjadi dua kategori yaitu : Dewasa adalah pengunjung yang berasal dari warga negara asing yang berasal dari masyarakat biasa yang sebaya dengan umur pelajar SMA maupu perguruan tinggi; Anak-anak adalah pengunjung yang berasal dari warga Negara asing yang berasal dari masyarakat biasanya dengan umur sebaya dengan anak TK maupun SD.Penelitian ini meninjau adanya kecenderungan peningkatan pengunjung di Museum Bali dari tahun 2002-2014.

\subsection{Bauran Pemasaran Sebagai}

\section{Penunjang Peningkatan Wisatawan}

Pemasaran dapat diartikan sebagai kegiatan dalam memindahkan barang dan jasa dari produsen ke tangan

konsumen yang membutuhkan secara

efisien, menguntungkan dalam persiapan

yang wajar (Novalina, 2008). Karena

museum merupakan organisasi non

profit artinya tidak memprioritas kepada

keuntungan maka pendekatan dan

strategi pemasaran yang dapat

diterapkan oleh museum adalah

pemasaran jasa (marketing service) yaitu

jasa untuk menambah ilmu pengetahuan

pengguna museum.

Timbul pertanyaan mengapa

promosi dan publikasi (advertensi) bisa

mempergaruhi peningkatan pengunjung

di Museum Bali, maka penulis menjawab

pertanyaan tersebut dengan

mengunakan teori yang umum

digunakan dalam pemasaran. Teori ini

sering disebut dengan bauran

pemasaran (marketing mix) yang banyak

dilakukan oleh para pengusaha dalam

mendulang peningkatan pendapatannya.

Lebih lanjut Purnamasari (2011: 21) 
manyatakan bahwa bauran pemasaran

adalah satu perangkat yang terdiri dari produk, harga, promosi dan tempat, yang didalamnya akan menentukan tingkat keberhasilan pemasaran dan semua itu ditujukan untuk mendapatkan respon yang diinginkan dari pasar sasaran.

Maka komponen utama dari bauran pemasaran ialah produk, harga, tempat, dan promosi. Keempat hal inilah yang mempergaruhi pemutusan seseorang dalam mengunjungi suatu tempat obyek wisata yang mana dalam konteks ini ialah Musum Bali. Perlu diketahui bahwa setiap wisatawan memiliki pandangan atau persepsi yang berbeda-beda. Dalam Tulisan ini, berusaha menganalisis faktor-faktor yang mempengaruhi keputusan wisatawan untuk berkunjung di Museum Bali yang meliputi produk, tempat, harga, dan promosi (marketing mix).

\section{Produk}

Produk yakni segala sesuatu yang dapat ditawarkan ke pasar untuk mendapat perhatian, dibeli, digunakan atau dikonsumsi yang dapat memuaskan keinginan atau kebutuhan. Produk dapat berupa objek secara fisik, jasa, orang, tempat, ide, organisasi, atau semua bentuk-bentuk tadi. Jika dikaitkan dengan museum maka produk yang dimaksud disini ialah, sesuatu yang diinginkan atau diperlukan oleh pengunjung, termasuk di dalamnya pameran, program-program museum serta berbagai fasilitas yang disediakan oleh museum.

\section{Museum Bali mempunyai} pameran tetap dan temporer sebagai produk utamanya. Pameran tetap yang disajikan di empat gedung dan satu gedung untuk pameran temporer. Koleksi yang tedapat di Museum Bali merupakan hasil dari budaya masyarakat Bali dari Masa Prasejarah hingga saat ini 
yang disajikan dengan apik dan menarik sesuai story line yang telah ditetapkan.

Pameran temporer digunakan memamerkan koleksi yang sifatnya sementara baik berasal koleksi Museum Bali atau dari pihak luar. ${ }^{3}$ Fasilitas lainnya yang disediakan di Museum Bali misalnya foto pra-nikah, yang mana Museum Bali dijadikan tempat untuk foto pra-nikah oleh masyarakat umum baik dari dalam maupun luar negeri.

\section{Harga}

Harga ialah sejumlah uang
(ditambah beberapa produk) yang dibutuhkan untuk mendapatkan sejumlah kombinasi dari produk dan pelayanannya atau pertukaran terhadap produk maupun pelayanan. Dalam kaitannya ini harga yang dimaksud adalah karcis masuk untuk memasuki Museum Bali, karena syarat utama pengunjung untuk

3 Hasil Wawancara dengan Dewa Putu Ardana umur 51 tahun, kepala Edukasi dan Prevarasi Museum Bali di Museum Bali pada tanggal 30 oktober 2014 dengan Yanni Pristyawati, staf Edukasi dan Prevarasi Museum Bali di Museum Bali pada tanggal 17 Nopember 2014. masuk ke Museum Bali ialah dengan membayar karcis dengan jumlah uang yang telah di tentukan. karcis masuk atau sering disebut dengan tiket masuk yang telah ditetapkan Museum Bali hingga saat ini ialah sebagai berikut untuk tamu asing: dewasa (10.000) dan anak-anak (5.000), sedangkan untuk tamu lokal: Dewasa (5.000), anak-anak (2.000), Mahasiswa (2.000), Pelajar (1.000) (Tim Penyusun Museum Bali, 2014: 9). Hal ini cukup relatif murah untuk standar Museum kelas nasional dengan tiket masuk yang demikian murah maka faktor ini juga menentukan dalam pemilihan tempat berkunjung.

\section{Tempat}

Tempat atau lokasi adalah sebuah titik tertentu yang dipilih oleh perusahaan untuk melaksanakan segala aktivitas usahanya, dimana titik tersebut mempunyai pengaruh terhadap strategistrategi usaha dari perusahaan yang bersangkutan (Purnamasari, 2011). 
Lokasi Museum Bali sangat strategis karena terletak di pusat kota Denpasar Sehingga sangat mempermudah bagi pengunjung untuk menemukan letak dan tempatnya. Berbagai fasilitaspun telah tersedia sebagai penunjang kegiatan berwisata seperti adanya jasa transportasi wisata, jasa perjalanan wisata, jasa makanan dan minuman, penyediaan akomodasi, penyelenggaraan kegiatan hiburan dan rekreasi, jasa informasi pariwisata dan lain sebagainya.

Hal tersebut selaras dengan apa yang dituangkan dalam Undang-undang Republik Indonesia Nomor 10.Tahun 2009 Tentang Kepariwisataan pasal 12 ayat satu yang berbunyi sebagai berikut :(1) Penetapan kawasan strategis pariwisata dilakukan dengan memperhatikan aspek: a). sumber daya pariwisata alam dan budaya yang potensial menjadi daya tarik pariwisata; b). potensi pasar; c). lokasi strategis yang berperan menjaga persatuan bangsa dan keutuhan wilayah; d). perlindungan terhadap lokasi tertentu yang mempunyai peran strategis dalam menjaga fungsi dan daya dukung lingkungan hidup; e). lokasi strategis yang mempunyai peran dalam usaha pelestarian dan pemanfaatan aset budaya; f). kesiapan dan dukungan masyarakat; g). kekhususan dari wilayah.

\section{Promosi}

Dalam pemasaran terdapat kegiatan promosi. Kemampuan dalam bidang promosi membantu kelangsungan pemasaran dalam mengenalkan sebuah produk. Promosi adalah upaya penyebarluasan informasi mengenai produk yang dihasilkan kepada khalayak umum sehingga masyarakat dapat mengetahuinya secara jelas. Dalam sebuah museum media untuk mempromosikan sangat banyak yang dapat digunakan seperti 
halnya media cetak seperti buku, brosur, booklet,folder, leaflet, buku panduan museum, majalah dan laporan yang relevan. Dengan teknologi informasi yang sangat maju seperti sekarang, penggunanan media massa juga sangat membantu dalam mempromosikan sebuah museum seperti website, email, faceebok, twitter, dan lain sebagainya. Museum Bali hingga saat ini telah melakukan berbagai promosi atau penyampaian informasi melalui website, brosur, VCD, dan lain sebagainya.

Empat komponen tersebut dikemas dan diolah sedemikian rupa untuk memasarkan sebuah museum. Dalam proses pemasaran hal yang paling penting ialah promosi karena jika produk yang baik, harga yang murah serta tempat yang strategis tidak diketahui oleh masyarakat maka akan sia-sia. Advertensi yang baik akan menarik masyarakat untuk mengetahui apa yang diinformasikan. Hal ini juga tidak terlepas dari peran biro perjalanan dalam mempromosikan Museum Bali sebagai salah satu obyek kunjungannya. Semakin banyak biro perjalanan yang beroperasi di Denpasar dan memasukkan Museum Bali sebagai paket wisatanya maka hal kemungkinan terjadi akan adanya peningkatan pengunjung. Lebih lanjut penulis mengutip hasil penelitiannya I Wayan Ardika yang menyatakan bahwa kunjungan wisatawan ke Museum Bali sangat ditentukan oleh sumber informasi melalui media cetak seperti brosur, buku, dan biro perjalanan. Dari $100 \%$ sekitar $82 \%$ menyatakan demikian. Hal tersebut menunjukkan bahwa peran advertensi sangat mempergaruhi wisatawan yang berkunjung ke Museum Bali.

\subsection{Promosi dan Publikasi di Museum}

Bali

Beberapa hal yang telah dilakukan oleh pihak museum guna memberikan informasi kepada 
masyarakat mengenai gambaran umum Museum Bali yang mana sampai saat ini masih dilakukan. Harapan yang ingin dicapai adalah masyarakat tumbuh kesadaran akan pentingnya mengunjungi suatu museum khususnya di Museum Bali. Adapun bentuk dari kegiatan tersebut adalah sebagai mana dijelaskan di bawah ini.

\section{Pameran Temporer}

Pameran temporer

diselenggarakan setiap tahun di Museum Bali. Biasanya pameran dilakukan dengan kegiatan Workshop dan Lomba. Penyelenggaraan ini dapat dibuktikan denga mengadakan pameran khusus pada tahun 2014 dari tanggal 21 juli sampai 9 agustus 2014 di Museum Bali dengan tema "Melalui Pameran Mengenai Motif Wayang Pada Peralatan Masyarakat Bali Kita Tingkatan Jati Diri Budaya Bangsa ". Karena Wayang merupakan hasil kebudayaan masyarakat Bali yang telah dikenal sejak dahulu. Wayang merupakan salah satu seni budaya pertunjukkan yang disajikan untuk keperluan upacara maupun hiburan (Ardana, 2014: 9).

Worskshop yang disebut dengan praktek kerja budaya dilaksanakan pada tanggal 24 juli 2014 dengan judul “ Menggambar Motif Wayang”. Kegiatan ini dilaksankan di SMK 2 Sukawati, Gianyar dengan sasaran kegiatan ditujukan kepada murid SMK tersebut dengan jumlah 150 siswa/siswa. Berdasarkan Laporan kegiatan tersebut tujuan yang hendak dicapai ialah mampu melestarikan wayang dikalangan generasi muda dan menumbuh kembangkan keahlian menggambar motif wayang dikalangan generasi muda. Kemudian untuk lomba juga dilaksanakan untuk anak-anak yang pada saat itu bertepatan dengan hari anak nasional. Kegiatan lomba bermaksud untuk memperkenalkan 
kembali permainan tradisional Bali yang disebut dengan "Dong Upih".4

Melalui kegiatan tersebut

Museum Bali selaku pengelola telah mempromosikan Museum Bali kepada masyarakat umum dari anak-anak, pelajar maupun dewasa. Hal ini merupakan langkah nyata guna memasarkan keberadaan dan menunjukkan eksistensi Museum sebagai lembaga yang mampu menarik dan menjadi obyek yang digemari oleh masyarakat luas. Dari kegiatan inipun masyarakat juga dapat mengetahui sekilas dari koleksi yang ada di Museum Bali. Kegiatan ini akan terus dilakukan dan diselenggarakan setiap tahunnya oleh pihak museum. Kemudian langkah kedepan akan ada rencana bahwa kegiatan ini ditambah dengan mengadakan sosialisai ke sekolahsekolah.

\footnotetext{
4 Hasil Wawancara dengan Yanni Pristyawati umur 40 tahun, staf edukasi dan prevarasi di Jalan ratna Gang Jepun 1 no. 7 pada tanggal 20 novemper 2014 .
}

Publikasi (Media Cetak, Media Massa)

$$
\text { Dengan adanya teknologi }
$$

infomasi yang sangat maju seperti sekarang harus diimbangi dengan sumber daya manusia sebagai pemakai atau penggunanya, untuk itu Museum Bali hendaknya mengikuti kemajuan IPTEK dengan melatih dan meningkatkan sumber daya manusianya. Dengan begitu museum dapat memanfaatkan IPTEK untuk memasarkan dan mempromosikan museum dengan lebih efisien dan efektif.

Berdasarkan data yang telah dikumpulkan. Museum Bali telah memanfaatkan media cetak dengan membuat sebuah brosur sejak tahun 1999, yang mana telah diketahui bersama saat itu Museum Bali masih di kelola oleh pemerintah pusat. Sampai sekarang Museum Bali masih mempergunakan brosur sebagai salah satu alat untuk memberikan informasi atau mempromosikan museum kepada 
masyarakat, cetakan terbaru hingga saat ini yaitu brosur bertahun 2014. Secara umum isi dari brosur menyebutkan ruang lingkup lokasi museum, kesejarahan dan koleksi-koleksi yang ada di setiap gedungnya. Kemudian ada sedikit perubahan-perubahan yang dilakukan mulai dari tampilan, penambahan isi dan yang terbaru ini mengunakan dua bahasa yaitu Inggris dan Indonesia.

Kemudian juga mengunakan media massa sebagai alat promosinya. Tidak heran masyarakat saat ini telah mengenal dengan adanya internet, dari anak-anak hingga yang sudah tua. Maka dari itu Museum Bali juga tidak mau ketinggalan untuk memanfaatkanya. Berdasarkan penelusuran di media maya Museum Bali telah mempunyai facebook yang dinamai dengan UPT. Museum Bali disana tercantum alamat, dan beberapa koleksi. Selanjutnya penulis juga menemukan Museum Bali di website Dinas Kebudayaan Provinsi Bali. Di
Google Maps dan Google+ juga menyebutkan letak dan lokasi Museum Bali. Paling populer saat ini ialah youtube, Museum Bali telah mengunggah tiga buah profile ke youtube dengan nama Museum Bali profile Part 1, Museum Bali profile Part 2 dan Museum Bali profile Part 3. Video klip terbaru ini dengan jelas memamparkan profile museum dengan bahasa yang mudah dan sederhana serta menarik, dari hal yang terkecilpun dipaparkan dengan apik.

Tidak sampai disitu ternyata Museum Bali atas prakarsa dari Dinas Kebudayaan provinsi Bali telah bekerja sama dengan salah satu stasiun televisi lokal yaitu Dewata TV. Dengan data yang ada diuraikan bahwa dalam rangka mensosialisasikan Museum Bali kepada masyarakat terutama generasi muda dan untuk meningkatkan kunjungan ke Museum Bali, maka upaya yang dilakukan ialah dengan membuat video 
klip lagu anak yang berjudul "Museum

Bali". Kemudian terkait dengan buku-

buku, jurnal-jurnal dan penelitian lainnya

banyak yang sudah ditulis tetapi sayang

sampai saat ini tulisan tersebut hanya

diletakkan di perpustakaan belum

dipublikasikan kepada masyarakat.

\section{Peran Biro Perjalanan Wisata dalam Mempromosikan Museum Bali}

Sebuah biro perjalanan wisata mempunyai ruang lingkup kerja antara lain Membuat, menjual dan menyelenggarakan paket wisata; Mengurus kebutuhan jasa angkutan bagi kelompok maupun perorangan yang diurusnya; Melayani pemesanan akomodasi penginapan, restoran, dan sarana wisata lainnya; Mengurus dokumen perjalanan; Menyelenggarakan pemanduan wisata; Menjamin keamanan dan kenyamanan kelompok maupun perorangan yang diurusnya.

Jika dilihat ruang lingkup kerjanya maka yang menjadi perhatian ialah membuat, menjual dan menyelenggarakan paket wisata. Dalam hal menjual maka sebuah Biro Perjalanan harus mampu mempromosikan dan memasarkan sebuah obyek wisata guna menarik wisatawan untuk mengunakan jasa tersebut. Strategi-strategi promosi sebuah Biro perjalanan Wisata antara lain yang dapat dilakukan adalah Personal selling atau sering disebut dengan penjualan tatap muka antara pembeli dengan penjual. Penjualan tatap muka adalah alat yang paling efektif pada tahap-tahap tertentu dari proses pengambilan keputusan tentang pelanggan terutama dalam keyakinan dan tindakan pembeli, sehingga penjual tahu betul maksud pembeli apalagi dengan persaingan harga yang semakin ketat. Kemudian dengan cara advertensi (periklanan) yaitu promosi lewat media massa online maupun ke media cetak berbayar maupun tidak bayar, cara ini 
juga dipandang efektif dan efisien untuk memasarkan sebuah perusahaan Biro Perjalanan Wisata (BPW). Cara-cara lain masih banyak yang dapat ditempuh oleh BPW.

BPW dalam memasarkan dan mempromosikan perusahaannya harus ada sebuh produk, produk disini ialah obyek yang dapat di kunjungi oleh wisatawan sebagai tempat wisata. Museum Bali sebagai salah satu obyek wisata maka dapat dijadikan produk yang dapat dikemas dengan sebuah paket wisata. Berdasarkan penelusuran di internet berbagai BPW sudah mengunakan media massa sebagai alat promosinya antara lain BPW bernama Bali Wisata Murah, Travel Agency, Balitour, Bali Denpasar Tour dan lainnya. Kemudian mencantumkan Museum Bali salah satu obyek kunjunganya. Dapat dilihat bahwa peran BPW dalam memasarkan sebuah museum khususnya Museum Bali juga mempergaruhi terhadap kedatangan wisatawan dan secara tidak langsung BPW juga berperan mempromosikan Museum Bali.

Di Denpasar sendiri jumlah tempat daya tarik wisata yang tercatat di Dinas Pariwisata berjumlah 27 obyek termasuk Museum Bali, kemudian dalam rangka program city tour kota Denpasar, ditetapkan 10 obyek wisata diantaranya adalah Museum Bali. Adapun jumlah BPW hingga tahun 2013 berjumlah 377.

\section{Kesimpulan}

Berdasarkan uraian di atas menunjukkan bahwa bauran pemasaran (marketing mix) sebagai salah satu perangkat yang mampu mendorong wisatawan berkunjung ke Museum Bali. Data pengunjung yang menunjukkan peningkatan, tidak lain bauran pemasaran yang menjadi faktor penentunya. Bauran pemasaran terdiri dari produk, harga, tempat, dan promosi. Keempat komponen ini dikemas 
sedimikian rupa hingga bermuara pada

pemutusan wisatawan Museum Bali.

Promosi dan publikasi menjadi tombak

paling depan dalam bauran pemasaran,

karena ia mampu menembus pasar

dalam Biro Perjalanan Wisata. Dengan

demikian pengunjung akan melek

dengan keberadaan Obyek Wisata

Museum Bali sebagai salah satu city tour

kota Denpasar.

\section{Daftar Pustaka}

I Wayan Ardika. 2008. Pusaka Budaya dan Pariwisata. Denpasar: Pusaka Larasan

Hari Karyono.tt. kepariwisataan. Jakarta: Gramedia

Ida Bagus Gede Adyaguhyaka, 2011. "Pengelolaan Museum Pusat TNI AU Dirgantara Mandala Sebagai Objek dan Daya Tarik Wisata di Kabupaten Bantul Yogyakarta (skripsi). Denpasar: Fakultas Sastra Universitas Udayana.

Gatot Ghutama dkk. 2008. Pedoman Museum Indonesia. Jakarta: Direktorat Museum.

Tim Penyusun Museum Bali, 2014. Buku Panduan Museum Bali. Denpasar: Pemerintah Provinsi Bali, UPT. Museum Bali.

Lifska Novalina, 2008. Peranan Promosi WIsata Di Dinas Kebudayaan dan Pariwisata Bandung dalam
Meningkatkan Motivasi Wisatawan terhadap Kota Bandung dan Sekitarnya. Bandung: Universitas Widyatama Bandung., diunduh via $\mathrm{http} /$ google.com dalam bentuk pdf tanggal 25 novemper 2014.

Yulia Endah Sukma Purnamasari, 2011. "Analisis Pengaruh Bauran Pemasaran Terhadap Keputusan Wisatawan Asing Berlibur Di Kota Semarang", skripsi S-1 Fakultas Ekonomi Universitas Diponegoro Semarang, di unduh via http.//google.com dalam bentuk pdf pada tanggal 24 nopember 2014.

Anonim, 2009. Undang-undang Republik Indonesia Nomor 10 tahun 2009 tentang Kepariwisataan. Jakarta: Sekretariat Negara RI, diunduh via Google.com pada tanggal 23 novemper 2014.

Widya Prima Natalia, 2012. Masjid Raya Ganting di Kecamatan Padang Timur, Kota Padang, Sumatera barat : Kajian bentuk dan fungsi skripsi S-1. Denpasar: Fakultas Sastra dan Budaya Universitas Udayana.

Dewa Putu Ardana, 2014. Laporan: Pekan Apresiasi Budaya Pameran Museum Tingkat Kabupaten. Denpasar: UPT Museum Bali.

Sumber internet: https://petatematikindo.files.wordpress.c om 